\title{
Comparison of Growth Traits and Yields Components of five Chickpeas Genotypes (Cicer arietinum L.) at Bakrajo/ Sulaymaniyah Conditions
}

\author{
Jalal Omer Ahmed \\ Industrial Food and Quality Control \\ Bakrajo Technical Institute \\ Sulaimani Polytechnic University \\ Sulaymaniyah, Iraq \\ jalal.ahmed@spu.edu.iq
}

\author{
Dara Yara Mohammad \\ Industrial Food and Quality Control \\ Bakrajo Technical Institute \\ Sulaimani Polytechnic University \\ Sulaymaniyah, Iraq \\ dara.ahmad@spu.edu.iq
}

\author{
Anwar Rashid Abdulla \\ Industrial Food and Quality Control \\ Bakrajo Technical Institute \\ Sulaimani Polytechnic University \\ Sulaymaniyah, Iraq \\ anwar.abdulla@spu.edu.iq
}

\author{
Chnar Hama Noori Meerza \\ Industrial Food and Quality Control Department \\ Bakrajo Technical Institute \\ Sulaimani Polytechnic University \\ Sulaymaniyah, Iraq \\ chnar.meerza@spu.edu.iq
}

\begin{abstract}
This study was carried out in Bakrajo Technical Institute, affiliates to the Sulaimania Polytechnic University. The investigation was done to find the relationships between genotypes and sowing times of five chickpeas (Cicer arietinum L.) during 2017-2018 seasons. Genotypes and sowing time are two significant variables which have impact on crop performance. However, heat stress throughout reproductive growth it is possible to cause Significant productivity loss. According to the environment conditions in winter season in the northern Iraq; crop meets slight heat and the acceptable moisture during reproductive growth and maturity. This leads to resulting in maximum and consistent yields, as well as there is a positive correlation between Maturity and Seed Yield $(\mathrm{kg} / \mathrm{h})$ as resulted from the experiment. Experimentation was laid out in a randomized complete blocks design (RCBD) with three replications applied. Results of analysis of variance outlined that there was significant difference between chickpeas varieties in the most of traits such as no. of branches per plant, $50 \%$ flowering, no. of pods per plant, leaf area, seeds weight per plant and the 100 seeds weight plus harvest index, which in turn give a share in to raise yields and yield components. Sowing time and varieties had significant effects on all measured trait, Ghab 1; Filip 2 and Filip 3 winters sowing genotypes gave higher seed yield, 1582.66, 1554.66 and $1533.33 \mathrm{Kg} / \mathrm{h}$ respectively. Minimum yield 662, $480 \mathrm{Kg} / \mathrm{h}$ was recorded in the Local and Swrka spring sowing genotype.
\end{abstract}

Keywords: Comparative, Chickpea, Growth traits, Genotypes, Sowing date, Yield Components.

\section{INTRODUCTION}

Kurdistan area of Iraq is somewhere located in southwest of Asia, among latitudes 34-37 and longitudes 41-46, with annual ranging from $350-1,200 \mathrm{~mm}$. This region is wealthy in both soil and water in form of rain in winter and spring seasons. Rain in an appropriate amount during winter and spring seasons; this may additionally let Kurdistan be one of the richest agricultural areas in the Middle East and all over the world for legume crops, especially chickpeas [1]. One of the most critical difficulties in the agriculture sector in developing countries is insufficient devotion to agricultural research. For this cause, work in agricultural research is considered a sacred responsibility for us to contribute as much as possible to the development of the agricultural area in the future [2]. In most of the scientific research's it has been indicated that Chickpea is the third main essential legume crops in the world after soybean and faba bean [3, 4]. Chickpeas contains high tiers of proteins (up to $30 \%$ ), and carbohydrates; additionally they supply a few minerals $(\mathrm{P}$, $\mathrm{Ca}, \mathrm{K}, \mathrm{Mg}, \mathrm{Zn}$ and $\mathrm{Fe}$ ) and nutritional vitamins like niacin as nicely as unsaturated fatty acids $[5,6]$. In Iraq, it considers as a second grain legume after Faba bean. It has been cultivating intensively in the north of the governorates including Sulaymaniah, Duhok in addition Erbil. According to published statistics data by the Ministry of Agriculture, the chickpeas, covering an area of 13,000 - 14,000 hectare with an average yield of 0.70 $-0.75 \mathrm{t} / \mathrm{ha}$ [7]. Despite the large area of the cultivation, still, the level of production and productivity are awfully low. Moreover, there is a vast gap amidst the probable yield and real yield almost in all developing countries of chickpea $[8,9]$. Chickpea is one of the main crops grown which it can be cultivated on low fertility and sandy loam soils in the world [10]. Generally chickpea considered one of the main important plants; this is for their significant contributor to agricultural sustainability via nitrogen fixation. Participating chickpea as a rotation crops allowing the diversification of agricultural production systems [11]. For that reason, it plays a major function in crop rotations in nearly all countries around the world, upon their growing in rotation with another crop, under proven ecological conditions. Soil fertility can be improved and the rate of weeds, diseases and pests can be 
decreased [12, 13]. Generally, Chickpeas grows as Mediterranean winter plants and depend on rain in the wet time, at the end of spring and summer as a whole (northern Iraq, Iran and Turkey). Following rain in a number of Mediterranean countries and South Asia depend on soil moisture stored [14]. Several varieties or genotypes of chickpea are cultivated throughout the world. Recognized Chickpeas for the Kurdish farmers are spring types. Regarding winter type they have no sufficient data about planting as well as their productions [15].Genotypes plus sowing time are the main significant factors affecting chickpea yield [16]. Determine the appropriate date for sowing chickpea plays a significant role in yield and yield components. Habitually delayed sowing date decreases growing period, maturity and reduces yield and yield components $[6,17]$. The goal of current study was to find out the best appropriate chickpeas genotypes or varieties of chickpea for the Bakrajo location. In order to achieve this goal we studied a number of growth traits and yields components. In addition to study the response of dissimilar varieties of chickpea in winter sows or spring sowing in Bakrajo.

\section{METHODS AND MATERIALS}

This experiment was conducted in the research area of Bakrajo Technical Institute; belong to the Sulaimani Polytechnic University (SPU) in Sulaymaniyah city during 2017-2018. The research site is situated at an altitude of $838 \mathrm{~m}$ above of sea level .Bakrajo located about approximately $7 \mathrm{~km}$ North West of Sulaymaniyah city center [18][19]. Research area's soil of Bakrajo Technical Institute belongs to (Clay Loam), soil physical structure analyses are appeared in table 01, [19][20]. Following the preparation of soil which chickpea was plant in lines, the full dimension among two lines was 0.3 $\mathrm{m}$. The area of boards $2 * 1.5 \mathrm{~m}\left(3 \mathrm{~m}^{2}\right)$, the seeds were sown in the winter and spring season. For the growing period; the temperature ranged between $10^{\circ} \mathrm{C}$ to $38^{\circ} \mathrm{C}$. During the experiment we have relied on rain only to irrigate the plants, without the use of supplementary irrigation, rainfall during the experiment was $641.9 \mathrm{~mm}$. The objective of the study was to obtain an accurate comparison in growth traits was including (plant height, number of branches, number of leaves, leaf area, total period to $50 \%$ flowering, and the period of getting to the maturity period). As well as comparison in yield components was including (number of pods, and seeds/pod, seeds weight, 100 seeds weight and seed yield). During the study we used five genotypes of winter and spring chickpea for comparison of (Ghab 1, Filip 2, Filip 3, Local and Swrka). The investigation was made by Randomized Complete Block Design 'RCBD', with three replications for five chickpea genotypes. Sowing date of the winter genotypes (Ghab 1, Filip 2 and Filip 3) was in $13^{\text {th }}$ of December, 2017. But the second date for sowing was $21^{\text {st }}$ of February, 2018 for the-spring genotypes (Local and Swrka). All of the plant traits data were recorded on 100 Chickpeas Plant. The grain yield $(\mathrm{Kg} / \mathrm{ha})$ for all of them was counted for all the plots .Data analysis was done by using SPSS for analysis [21, 22].

Table 01: Soil Components Structure Analyses - Bakrajo Location

\begin{tabular}{|c|c|c|c|c|c|c|c|c|c|c|}
\hline $\begin{array}{l}\text { Soil Structure } \\
\text { properties }\end{array}$ & EC & $\mathrm{pH}$ & $\% \mathbf{N}$ & $\begin{array}{c}\text { Available P } \\
\text { (ppm) }\end{array}$ & $\begin{array}{c}\text { Soluble } \\
\text { Na } \\
\text { Meq/L }\end{array}$ & $\begin{array}{c}\text { Soluble } \\
\text { K } \\
\text { Meq/L }\end{array}$ & $\begin{array}{c}\text { Soluble } \\
\text { Ca } \\
\text { Meq/L }\end{array}$ & \%Sand & \%Silt & $\%$ Clay \\
\hline Soil Sample & 0.32 & 7.09 & 0.23 & 27.9 & 0.222 & 0.359 & 11.61 & 12.09 & 46.12 & 41.78 \\
\hline
\end{tabular}

\section{RESULTS AND DISCUSSION}

\section{Analysis of variance:}

Based on deferential investigation appeared in the Tables 02\&03 durability, significant differences were identified between genotypes in chickpea in the all traits except number of seeds per pod. Throughout those results, the effect of these varieties for improving growth traits and yield has been showed. The numbers of growth traits increased gradually by application of these genotypes. At the same time the data demonstrated high potentials of the genotypes to get better chickpea yields. Results proofed that the applying of these genotypes on characters such as, number of branch per plant, number of leaves / plant, leaf area/plant, days to $50 \%$ flowering, days to maturity, seeds weight/ plant, 100 seeds weight and yield per hectare, plant height, No. of pods / plant were significant while the No. of seeds/ pod were not significant at the both level probabilities.

Table 02: Analysis of variance (RCBD) for studied Growth traits of Chickpea Genotypes

\begin{tabular}{|c|c|c|c|c|c|c|c|}
\hline \multirow[b]{2}{*}{ S.O.V } & \multirow[b]{2}{*}{ d.f. } & \multicolumn{6}{|c|}{ MS } \\
\hline & & $\begin{array}{l}\text { Plant } \\
\text { Height } \\
(\mathrm{cm})\end{array}$ & $\begin{array}{c}\text { No. of } \\
\text { Branches/ } \\
\text { plant }\end{array}$ & $\begin{array}{c}\text { No. of } \\
\text { Leaves / } \\
\text { plant }\end{array}$ & $\begin{array}{l}\text { Leaf area } \\
\left(\mathrm{cm}^{2} \text { plant }\right)\end{array}$ & $\begin{array}{c}50 \% \\
\text { Flowering }\end{array}$ & $\begin{array}{l}\text { Maturity } \\
\text { ( day) }\end{array}$ \\
\hline Replication & 2 & 4.26 & 3.95 & 43.40 & 100.89 & 11.27 & 0.20 \\
\hline Treatment & 4 & $52.95 *$ & $10.90 * *$ & $1666.00^{* * *}$ & $1123.58 * *$ & $1505.98 * *$ & $3305.23^{* *}$ \\
\hline Error & 8 & 12.33 & 2.36 & 40.90 & 31.86 & 32.05 & 1.20 \\
\hline
\end{tabular}

Table 03: Analysis of variance (RCBD) for studied Yield Components of Chickpea Genotypes 


\begin{tabular}{|c|c|c|c|c|c|c|}
\hline \multirow{2}{*}{ S.O.V } & \multirow{2}{*}{ d.f. } & \multicolumn{5}{|c|}{ MS } \\
\hline & & $\begin{array}{l}\text { No. of Pods / } \\
\text { plant }\end{array}$ & $\begin{array}{c}\text { No. of } \\
\text { Seeds/ pod }\end{array}$ & $\begin{array}{l}\text { Seeds weight/ } \\
\text { plant (gm) }\end{array}$ & $\begin{array}{l}100 \text { Seeds weight } \\
(\mathrm{gm})\end{array}$ & Yield $(\mathrm{kg} / \mathrm{h})$ \\
\hline Replication & 2 & 12.64 & 0.016 & 1.38 & 2.13 & 16568.26 \\
\hline Treatment & 4 & $77.84 *$ & 0.03 & $482.39 * *$ & $429.87 * *$ & $888118.93 * *$ \\
\hline Error & 8 & 15.33 & 0.038 & 0.34 & 4.05 & 15806.93 \\
\hline
\end{tabular}

\section{Comparing of Means:}

\section{A.Growth traits of Chickpea Genotypes :}

i. Plant Height: The final Plant height has been appeared in the Table 04. The amount of variation is that Filip2 is higher than every one of other genotypes. Conversely as shown in the specified table 04 , Swrka has got the minimum height compared to the others.

ii. Number of branches / plant: The difference among the final number of the plant's brunches showed in Table 04. Filip3 could get the maximum number of branches which is higher than the other genotypes. As it can be notice in the same table that Local variety has the minimum number of the brunches per plant.

iii. Number of Leaves / plant: The average of the final number of the leaves per plant identified in the Table 04. The ration of the Ghab's 1 was higher than the other genotypes. While Swrka has got the minimum number of the leaves per plant. Finally, the mean difference is statistically significant in the case of chickpea genotypes treatment among all of the genotypes.

iv. Leaf Area: In the Table 04 the difference of the final leaf area per plant has been demonstrated. Swrka has got the minimum leaf area. In the case of chick pea genotypes treatment, the difference is vividly significant in compare to the other genotypes.

v. 50\% flowering: Regarding the process of 50\% flowering, the Table 04 shows the means among the all of the genotypes. Ghab 1 has got $50 \%$ of flowering after the other genotypes. The period required for $50 \%$ flowering is very short in Local genotypes compared to all of the other genotypes.

vi. Maturity: Table 04 clarifies the total number of the days that needed for the genotypes to get the maturity stage. The mean of Filip 2 and Filip 3 is the same and the appropriate period for maturity is long compared to other. At the same time Local got the minimum days to maturity. The mean difference is statistically significant in the case of chickpea genotypes treatment, compared to in all other genotypes.

Table 04: Mean comparisons in Growth traits of Chickpea Genotypes

\begin{tabular}{lcccccc}
\hline Plant Traits & $\begin{array}{c}\text { Plant Height } \\
(\mathrm{cm})\end{array}$ & $\begin{array}{c}\text { No. of } \\
\text { Banches } / \\
\text { plant }\end{array}$ & $\begin{array}{c}\text { No. of Leaves } \\
\text { / plant }\end{array}$ & $\begin{array}{c}\text { Leaf Area } \\
\left(\mathrm{cm}^{2} \text { Plant }\right)\end{array}$ & $\begin{array}{c}50 \% \\
\text { Flowering }\end{array}$ & $\begin{array}{c}\text { Maturity } \\
\text { (day) }\end{array}$ \\
\hline Ghab 1 & $38.06 \mathrm{~b}$ & $8.66 \mathrm{~b}$ & $109 \mathrm{a}$ & $13.05 \mathrm{~b}$ & $117.00 \mathrm{a}$ & $192.66 \mathrm{a}$ \\
Filip 2 & $45.50 \mathrm{a}$ & $9.33 \mathrm{a}$ & $108 \mathrm{a}$ & $14.35 \mathrm{a}$ & $115.33 \mathrm{a}$ & $193.33 \mathrm{a}$ \\
Filip 3 & $40.53 \mathrm{a}$ & $10.33 \mathrm{a}$ & $98 \mathrm{~b}$ & $14.40 \mathrm{a}$ & $114.33 \mathrm{a}$ & $193.33 \mathrm{a}$ \\
Local & $39.90 \mathrm{~b}$ & $6.33 \mathrm{c}$ & $91 \mathrm{~b}$ & $11.13 \mathrm{c}$ & $69.00 \mathrm{c}$ & $129.00 \mathrm{~b}$ \\
Swrka & $33.90 \mathrm{c}$ & $6.83 \mathrm{c}$ & $59 \mathrm{c}$ & $10.09 \mathrm{c}$ & $80.00 \mathrm{~b}$ & $135.66 \mathrm{~b}$ \\
\hline
\end{tabular}

\section{B. Yield Components of Chickpea Genotypes:}

i. Number of pods /plant: Each of the genotypes recorded different pods per plant. Table 05 , identifies the means in the final results of the pods per plant. Swrka was highest while Filip 2 was lowest number of pods/plant. The statistically mean difference can be seen in the case of chick pea genotype treatment in compare to all of the other genotypes.

ii. Number of Seeds / pod: In the Table 05 the number of the seeds per pod has been showed. The number of seed per pod of Ghab1, Filip 3 and Swrka are higher than Flip 2 and Local .The mean difference is statistically significant in the case of chickpea genotypes treatment in compare to the other genotypes. iii. Seeds weight / plant: The total weight of the seeds per each plant have been recorded and showed in the table 05 also. The mean of Ghab 1 is the higher than all of the other genotypes. Swrka has had the minimum seeds weight per plant consider to the other genotypes. There is also a statistical mean difference in the chickpea treatment at the same time.

iv. 100 seeds weight: The final weigh of the 100 seeds have been showed in the Ttable 05, Ghab 1 have been recorded heavier weight than the others while Swrka has had the lightest weight among the other genotypes. 
v. Yield $(\mathbf{K g} / \mathbf{h})$ : The last results of the seed yield have been demonstrated in the Table 05, the yield of Ghab 1 is more than the other genotypes. As shown in the mention table, Swrka has the minimum Seeds weight. Eventually the yield is reduced because the weight of Swrka genotype is very low-weight.

Table 05: Mean comparing in Yield Components of Chickpea Genotypes

\begin{tabular}{lccccc}
\hline Plant Traits & $\begin{array}{c}\text { No. of Pods / } \\
\text { plant }\end{array}$ & $\begin{array}{c}\text { No. of Seeds / } \\
\text { pod }\end{array}$ & $\begin{array}{c}\text { Seeds weight / } \\
\text { plant }(\mathrm{gm})\end{array}$ & $\begin{array}{c}100 \text { Seeds } \\
\text { weight/ (gm) }\end{array}$ & Yield (kg/h) \\
\hline Ghab 1 & $22.83 \mathrm{c}$ & $1.33 \mathrm{a}$ & $37.09 \mathrm{a}$ & $43.25 \mathrm{a}$ & $1582.66 \mathrm{a}$ \\
Filip 2 & $21.93 \mathrm{c}$ & $1.20 \mathrm{a}$ & $35.90 \mathrm{a}$ & $34.80 \mathrm{~b}$ & $1533.33 \mathrm{ab}$ \\
Filip 3 & $27.33 \mathrm{~b}$ & $1.33 \mathrm{a}$ & $35.70 \mathrm{a}$ & $39.36 \mathrm{ab}$ & $1554.66 \mathrm{~b}$ \\
Local & $27.10 \mathrm{~b}$ & $1.10 \mathrm{a}$ & $15.42 \mathrm{~b}$ & $38.13 \mathrm{~b}$ & $662.00 \mathrm{~b}$ \\
Swrka & $34.80 \mathrm{a}$ & $1.33 \mathrm{a}$ & $11.22 \mathrm{c}$ & $12.91 \mathrm{c}$ & $480.00 \mathrm{c}$ \\
\hline
\end{tabular}

\section{CONCLUSION}

The current investigation appears that dissimilar genotypes have had a significant effect. Every measured growth traits have had significant effect excluding number of seeds/ pod. As shown clearly in the result lowest amount yield was recorded in Swrka and Local spring genotype. Moreover, the highest yield was recorded in Ghab 1, Flip2 as well as Flip3 winter genotype. Genotype and sowing time are two significant influences which were affecting the growth traits and yield of legume crops such as chickpea. Conventionally, chickpea is sown in spring. Depending on the result of this investigation it can be recommended that winter genotypes are the most suitable verities for cultivation inside Sulaymaniyah. December is the greatest and suitable planting time for chickpeas cultivation. Furthermore it was concluded that, plant height, number of branches per plant, $50 \%$ flowering, leaf area, number of seeds per pod, seeds weight per plant and the 100 seeds weight, were the main important characters which contribute to yield and yield components of chickpea.

\section{REFERENCES}

[1] A.R.Abdulla, "Comparison of Six Different Wheat Genotypes (Triticum Spp.) and Effectiveness of Some Growing Characters and Yield," Middle-East Journal of Scientific Research 23( 9), pp.2264-2269, 2015.

[2] N. Abdul-Razzak Tahir, and D.A. Omer, "GENETIC VARIATION IN LENTIL GENOTYPES BY MORPHOAGRONOMIC TRAITS AND RAPD-PCRThe," Journal of Animal \& Plant Sciences, 27.(2), pp. 468-480, 2017.

[3] S. Hossein Vafaei, N. Azadbakht and R. derikvand, "Integrated management of Ascochyta Blight of Chickpea in Lorestan Province of Iran," Technical Journal of Engineering and Applied Sciences, 3(4) , pp. 294-297, 2013.

[4] A. Namvar; R. S. Sharifi,and T.Khandan, "Growth analysis and yield of chickpea (Cicer arietinum L.) in relation to organic and inorganic nitrogen fertilization," Ekologija, 57(.3), pp. 97-108, 2011.

[5] H. Han and B. K. Baik, "Antioxidant Activity and Pheno-lic Content of Lentils (Lens culinaris), Chickpeas (Cicer arietinum L.), Peas (Pisum sativum L.) and Soybeans (Glycine max), and Their Quantitative Changes during Processing," International Journal of Food Science and Technology, 43(11) , pp. 1971-1978, 2008.

[6] W.J, Kaiser; A.M, Ghanekar;Y.L. Nene;B.S. Rao \& V. Anjaiah,” Viral diseases of chickpea. In: Proceedings of the Second
International Workshop on Chickpea Improvement", Chickpea in the Nineties, pp. 139-142, 1990.

[7] G. S. Hussein, "Effect of sowing date and herbicides on Chickpea (Cicer arietinum L.) growth, yield, yield components and companion weeds under rain-fed conditions at Duhok governorate, “ Kufa Journal for Agricultural Sciences, 9(2), pp. 263-291, 2017.

[8] P. S, Sharma, PM. Gaur, S. Tripathi, L. Kaur, A. Basandrai, T. Khan, C.L. Gowda and KHM. Siddique, "Development of screening techniques and identification of new sources of resistance to Ascochyta b. Llight disease of chickpea," Australasian Plant Pathology, 40, pp.149-156, 2011.

[9] SH. Sabaghpour, D.Shariari, F. Mahmoodi, K. and Keshavarz, M. Selati, " Performance of new Ascochyta blight resistance chickpea,"Paper presented at the $16^{\text {rd }}$ Iranian Plant Protection Congress,University of Tabriz,Tabriz, Iran, 2004.

[10] K. Ahmed and M. S. Awan, "Integrated management of insect pests of chickpea (Cicer arietinum L.) in South Asian countries: Present status and future strategies - A review," Pakistan J. Zool, 45(4) , pp. 1125-1145, 2013.

[11] YT. Gan, KHM. Siddique, WJ. MacLeod and P. Jayakumar, “ Management options for minimizing the damage by ascochyta blight (Ascochyta rabiei) in chickpea (Cicer arietinum L.), "Field Crops Research , 97, pp.121-134, 2006.

[12] Wa. N. Chemining, and K. Vessey, "The abundance and efficacy of Rhizobium leguminosarum bv. viciae in cultivated soils of eastern Canadian prairie," Soil Biology \& Biochemistry 38, pp. 294- 302, 2006.

[13] S. Albayrak, C.S. Sevimay and O. Tongel, "Effect of inoculation with Rhizobium on seed yield and yield components of common vetch (Vicia sativa L.)," Turkish Journal of Agriculture and Forestry, 30, pp. 31-37, 2006.

[14] V. Devasirvatham, D. K. Y. Tan, P. M. Gaur, T. N. Raju A and R. M.Trethowan, "High temperature tolerance in chickpea and its implications for plant improvement," Crop and Pasture Science, 63(5), pp. 419-428, 2014.

[15] S. Ozdemir and U. Karadavut, "Comparison of the performance of autumn and spring sowing of chickpeas in a temperate region," Turkish Journal of Agriculture and Forestry 27, pp.345-352, 2013.

[16] S. Abbo, D. Shtienberg, J. Lichtenzveig, S. Lev- Yadun and A.Gopher, " The chickpea summer cropping and a new model for pulse domestication in the ancient near east," The Quarterly Review of Biology 78, pp. 435-438, 2003.

[17] K. Shamsi, "The effect of sowing date and row spacing on yield and yield components on Hashem chickpea variety under rain fed condition, "African Journal of Biotechnology, 9 ( 1), pp. 007-011, 2010.

[18] A.R. Abdulla, J. O.Ahmed and S. Q. Mahmood, "Comparisons of Six Hybrids Corn (Zea mays L.), in Terms of Yields and Components in Sulaimania," American-Eurasian J. Agric. \& Environ. Sci, 15(.5), pp. 848-852, 2015.

[19] J. O. Ahmed, A. R Abdulla and R.A. Mohammed, "Comparative on yield and its components performance and correlation in some Broad bean (Vicia faba L.) genotypes at Bakrajo, 
Sulaimani,“ American-Eurasian J. Agric. \& Environ . Sci, 16(.3) , pp. 635-640, 2016.

[20] D.Y. Mohammad, J. O. Ahmed, N. A. L. M. Albadree and A.R.Abdulla, "THE EFFECTS OF SEED'S SIZE, AND REMOVAL TESTA TREATMENT ON GERMINATION RATIO AND PERIOD OF FABA BEAN STORED SEEDS (VICIA FABA VAR. ECUADELJE), " International Journal of Research - GRANTHAALAYAH, 6( 3) , pp. 191-201, 2018.

[21] O. Sadeghipour and P. Aghaei, " Comparison of autumn and spring sowing on performance of chickpea (Cicer arietinum L.) Varieties, “International Journal of Biosciences, 2(6) , pp. 49-58, 2012.

[22] C. Iliadis, "Evaluation of six chickpea varieties for seed yield under autumn and spring sowing," Journal of Agricultural Science 137, pp. 439-444, 2001. 